\title{
Evolving Relationship between the Buddhist Monastic Order and the Imperial States of Medieval China
}

\section{Mario Poceski*}

The article explores central aspects of the relationship between the Buddhist monastic order and the various imperial states that ruled China during the medieval period (roughly between the third and the tenth centuries $\mathrm{CE}$ ). It focuses especially on the points of tension created by the monastic order's efforts to establish a sense of autonomy and receive special economic, political, or social exemptions on one hand, and the royal imperium's assertion of absolute authority over all subjects on the other hand. While the monastic order's efforts to safeguard its independence and ward off the encroachment of a totalitarian state was largely a losing proposition, in a protracted process that involved complex socio-political negotiations and shifting religious realignments, the Buddhist clergy was able to secure important exemptions from the Chinese rulers' demands. Most notably, these included exemptions from certain forms of taxation, military conscription, and forced labour, which helped secure the economic foundations of monastic life and enhance the prominent place of Buddhism in Chinese society. To illustrate these issues, the article explores some of the key debates that pitted prominent Buddhist monastics such as Huiyuan (334-416) against key segments of the Chinese socio-political elites, many of whom were influenced by a Confucian ideology that was often inimical to monastic institutions.

Keywords: medieval China; Buddhism; Huiyuan; monastic order

\section{Introduction}

Within the broad context of East Asian history, among the most important large scale events that unfolded during the early centuries of the Common Era was the introduction and spread of Buddhism into China. Initially the foreign faith - primarily brought in by itinerant monks and Central Asian merchants - grew gradually, but over the course of several centuries it became the strongest and most popular religious tradition in China. Buddhism brought many new elements that greatly affected and enriched Chinese civilization. At the same time, over the course of its growth in the Middle Kingdom, the religion also underwent significant changes, as it faced the challenges of adapting to the cultural norms and social realities

* Correspondence details: Mario Poceski, Religion Department, 132 Anderson Hall, University of Florida, Gainesville, FL 32611-7410, USA. Email: mpoceski@ufl.edu. 
of the host country, as well as adjusting to the spiritual needs and intellectual predilections of its people. Among the many important developments that took place during this turbulent but fascinating epoch in Chinese history was the gradual establishment of some of the basic power relations, legal strictures, and institutional arrangements that came to characterize the church vis-à-vis its relationship with imperial China.

Broadly conceived, this article explores some of the major aspects of the relationship between the Buddhist Sangha (the monastic order) and the various imperial dynasties that ruled China during the early medieval period (approximately between the third and the sixth centuries $\mathrm{CE}$ ), although in relevant places the coverage also extends into the late medieval period, especially the Tang 唐 dynasty (618-907). It is meant to serve as a wide-ranging survey of the topic, geared towards a broad audience that includes non-specialists; in this light, a substantial portion of the article is dedicated to providing an overview of the key issues and historical developments that shaped the state vs. church relationship in the Chinese context.

The article's focus is on some of the points of tension created by the seemingly irreconcilable worldviews and divergent institutional objectives that pitted the autocratic Chinese state(s) against the growing monastic order. On one hand, there were the monastic order's efforts to establish a sense of autonomy, receive economic and social exemptions, and secure legal prerogatives. At the same time, there was the royal imperium's assertion of absolute authority, accompanied with its persistent efforts to safeguard its capacity to impose various kinds of demands on all of its subjects.

These issues took central stage during the crucial periods of formative growth of Buddhism in China, and in due course they also had an impact on the transmission of Buddhism from China to the rest of East Asia. On the whole, the Sangha's efforts to safeguard a semblance of independence and ward off the encroachment of the totalitarian state was largely a losing proposition. Nonetheless, in a protracted historical process that involved complex socio-political negotiations and shifting religious realignments, the Buddhist clergy was able to secure important exemptions from the Chinese rulers' demands - most notably exemptions from taxation, military conscription, and forced labour. That, in turn, helped secure the economic foundations of monastic life and anchor the prominent place of Buddhism in medieval Chinese society.

More narrowly, the second half of the paper surveys some of the key debates that pitted prominent Buddhist monastics, such as Huiyuan 慧遠 (334-416), against key segments of the Chinese socio-political elites, many of whom were influenced by a prevalent form of Confucian ideology that was often inimical to monastic ideals and institutions. At their core, these protracted debates aimed at adjudicating the place of Buddhism in Chinese society, and setting the basic parameters that delineated the relationship between the Sangha and the imperial state. Nonetheless, it is interesting to note that in the Chinese context much of the external focus of the debates involved disputes and tussles over largely symbolic issues. Prime examples include the intertwined debates about whether monks should perform ritual bows in front of the emperor - examined in some detail later in the article - and pay ceremonial respects to their parents, as expressions of the prime Confucian virtues of obedience to authority and filial piety. 


\section{Chinese worldviews and institutions}

When Buddhism entered China during the first century of the Common Era, the early followers and missionaries encountered a large and dominant empire, with a long history and well-established institutions. The Han 漢 dynasty (206 BCE-220 CE) ruled a vast area that, in addition to the traditional Chinese headland, also stretched westward into Central Asia and eastward into the Korean peninsula. The power and influence of the Eastern Han dynasty (25-220 CE), while perhaps less impressive than that of the Western Han dynasty (206 BCE$8 \mathrm{CE}$ ), still evoke comparisons with the Roman Empire in the West. ${ }^{1}$ The empire's continued ability to control diverse local populations inhabiting a huge geographical domain was predicated on the existence of common political and cultural frameworks, which were already firmly established during the Western Han era.

By this time, Confucianism was recognized as a major element in social, political, and religious life, albeit within a larger pluralistic framework that allowed for contesting ideologies and alternative worldviews. The initial official acts that signalled an imperial endorsement of Confucianism took place during the rule of Emperor Wu 武帝 (r. 140-86 BCE), whose illustrious reign is often depicted as a high point of Han civilization. The long-ruling emperor was inspired by a syncretic Confucian system articulated by prominent scholars such as Dong Zhongshu 董仲舒 (c. 179-104 BCE). The new Confucian synthesis was meant to facilitate the establishment of a harmonious relationship between Heaven (tian 天) and the human realm, and by extension to glorify the emperor and his empire. To a large degree, the embrace of Confucianism as an official ideology of the imperial state by Emperor Wu and his successors was also predicated on political calculation and administrative expediency.

Within the highly centralized system envisioned by Confucian scholars and ideologues, the Chinese ruler wielded absolute power as the Son of Heaven (tianzi 天子), ruling over the whole world (tianxia 天下, lit. "all under heaven«). His absolute power and authority were predicated on the notion that he is in possession of "the mandate of Heaven « (tianming 天 命). This came together with an expectation that the ruler would serve as a moral exemplar and exercise his royal prerogatives in a paternalistic manner, taking into account the general welfare and daily needs of the people. In practical terms, it meant that the emperor exercised royal authority and temporal power on behalf of Heaven, which acted as a moral agent and had ultimate control over human existence.

Such ideas represented a repackaging of ancient political and philosophical ideas that went back to the Western Zhou 西周 era (1122-771 BCE), which Confucius and his followers regarded as a golden age of Chinese civilization. At a basic level, this implied a divine sanction for existing governmental institutions and power arrangements. In his august role as the ruler of all, the emperor was helped by numerous scholar-officials ( $\operatorname{sh} i \pm$ ), primarily recruited from within Confucian circles, who constituted the imperial bureaucracy. The privileged status of Confucianism was further bolstered by the educational system, including the official system of examinations first instituted during the Han era, in which the Confucian classics played a central role. 
Within the applied framework of Han politics and institutions, the ethical idealism of classical Confucian was combined with the utilitarian statecraft and shrewd realpolitik of Legalism (fajia 法家), which provided a coherent system of political philosophy as well practical tools for governance. The Legalist system advocated strong authoritarian rule, effective administrative structures, and pervasive social control. It was also characterized by a strict penal code and ruthless suppression of all challenges to the state's power and authority. In the end, the Chinese state adopted a hybrid form of governing ideology and bureaucratic structure, which combined the lofty ideals of humanistically-oriented Confucian moralism and the hardnosed realpolitik of Legalist authoritarianism. This conception of a Confucianlegalist state remained highly influential throughout later Chinese history. ${ }^{2}$ Clear echoes of it can still be discerned in the governing ideology and the political institutions of contemporary China, notwithstanding their communist veneer.

The pervasive power and totalitarian foundation of the unified imperial state are perhaps best conveyed by the expression wangzhe wuwai 王者無外 (lit. "nothing is outside of the king «), which can more widely be rendered as »there is nothing outside of the purview of the king's (emperor's) power and authority. ${ }^{3}$ This implies that everything and everybody is included under the emperor's vast dominion. Naturally, this includes all forms of personal piety and organized religion. In essence, the authority of the emperor encompassed both the secular and the religious spheres, although the basic distinction between the two - or between church and state, as understood in the West - is not necessarily applicable in the ancient Chinese context.

Accordingly, with the help of its Confucian officials, the state tried hard to exert comprehensive control over all religious forces within its realm, attempting to deploy them in the service of the existing power structures. ${ }^{4}$ Within such a system, the existence of an autonomous priesthood or other independent holders of authority not controlled by the government were highly problematic, inasmuch as they could pose a challenge to the political status quo or develop into alternative centres of power. The state's obsession with control was such that at various times it attempted to extend its control into the pantheon of popular Chinese religion, which to a large degree was modelled on the imperial bureaucracy. ${ }^{5}$

\section{Domestication of institutional religion}

Generally speaking, the status of religion and its relationship with the state was not a major issue in ancient China, where there was nothing analogous to Christianity, Judaism, Buddhism, Jainism, or other large institutional religions of the kind that existed elsewhere. Even Daoism, usually identified as a major Chinese religion, did not really exist in an institutional sense before the second century $\mathrm{CE}$, and the development of its doctrines and institutions was greatly influenced by Buddhism. Therefore, the incorporation of organized religion into

3 The classical source for this oft-cited expression is Gongyang zhuan 公羊傳 (Yin 1.6). This is one the three main commentaries of the Spring and Autumn Annals (Chunqiu 春秋), an important Confucian classic that traditionally is attributed to Confucius. See also Gentz, Long Live the King!, 77-78. Yang, Religion in Chinese Society, 180.

5 See Feuchtwang, Popular Religions in China, and Hansen, Changing Gods in Medieval China. 
the imperial system really became a main issue only after Buddhism was introduced into China. The situation was made more complex due to the fact that the new religion was primarily represented by its monastic order, which had no clear parallels in traditional Chinese society.

The wangzhe wuwai adage implied a Sino-centric conception of the world, and the term tianxia was conventionally used to refer to the Chinese empire. This had practical ramifications, since the grand concept of universal kingship - centred on the mythical image of the emperor as the Son of Heaven, who rules over the whole world - clashed with the experiential reality of non-Chinese states, over which the Chinese ruler often had little or no control. This reinforced the deeply ingrained distinction between Chinese and civilized on one hand, and foreign and barbarian on the other. ${ }^{6}$ At times, this kind of differentiation had racial or ethnic undertones. Nonetheless, by and large it was primarily deployed to highlight cultural distinctions, namely the deeply ingrained notion that China alone was fully civilized and its culture was superior to the cultures of other people.

This sort of cultural chauvinism was occasionally mixed or accentuated with other xenophobic elements. Nonetheless, there was no insurmountable racial gap that separated the Chinese and the non-Chinese. The operative assumption was that barbarians could be Sinicized, if they saw the light and accepted Chinese culture and institutions. This opened some space for the acceptance of foreigners, but the deeply entrenched presence of Sino-centric attitudes still created various sorts of problems for a foreign religion such as Buddhism. Moreover, as we will see below, the arrival of Buddhism brought serious challenges not only because the new religion brought an array of novel ideas and unfamiliar practices, but also because its ideals and institutions seemed inimical to entrenched cultural values, or did not fit neatly into central aspects of social life.

\section{Monastic mores and ideals}

One of the key features of Buddhism, which goes back to the founding of the religion in ancient India, was its emphasis on monasticism. The origins of Buddhist monasticism can be traced back to the śramana (shamen 沙門; lit. renunciates or ascetics) traditions that flourished in ancient India around the time of the Buddha (c. 480-40o BCE?). ${ }^{7}$ The śramana movement was diverse and included other notable traditions such as Jainism. Among its basic features was the adoption of a distinctive religious lifestyle - deemed conducive to a spiritual quest for higher knowledge - that tended to encompass asceticism, wandering, and mendicancy. It followers were also known for their rejection of the prevalent Brahmanical orthodoxy, which included a rejection of the Vedas and the caste system.

The establishment in the fifth century BCE of the Buddhist monastic order, the Sangha (lit. "community «), was a singular event in the history of religion. From its inception, the order included both male and female monastics, known in Sanskrit as bhikșu (C: biqiu 比 丘) and bhikșun̄i (C: biqiuni 比丘尼). ${ }^{8}$ In addition to the order's leading role in the growth and transmission of a great world religion, the development of discrete monastic ideals and

6 See Pan, Son of Heaven and Heavenly Qaghan, 22-24.

7 See Mizuno, Beginnings of Buddhism, 5-8; Hirakawa and Groner, History of Indian Buddhism, 15-19.

8 For the role of nuns in South Asian Buddhism, see Dewaraja, Buddhist Women in India and Precolonial Sri Lanka; for East Asian Buddhism, see Meeks, Nuns and Laywomen in East Asian Buddhism. For canonical formulations of monasticism within the Theravāda tradition, see Wijayaratna, Buddhist Monastic Life. 
institutions had a host of significant cultural, social, political, and economic ramifications, within and outside of India. The Sangha was conceived as an ideal community dedicated to the quest for truth and spiritual awakening, although in reality the order attracted all sorts of characters, both saints and scoundrels.

According to canonical formulations, monks (and nuns) were supposed to live pure and self-controlled lives regulated by the Vinaya, the monastic code of discipline, ${ }^{9}$ even if the degree of observance of the monastic precepts differed at various times and places. The monastic rules were meant to regulate various aspects of daily activity and organize religious life in ways that reflected central Buddhist beliefs and values. They codified an institutional structure that, in theory at least, was supposed to create communal conditions that were conducive to the cultivation of virtue and wisdom. To that end, they helped mould the internal attitudes and external behaviours of individual monks, by reinforcing central monastic ideals and facilitating canonically-sanctioned forms of spiritual cultivation.

Buddhist monastics constituted a large and well-ordered group of religious who were separate from the rest of society, with their own rules, procedures, rituals, mores, and practices. On a basic level, the act of becoming ordained as a monk (S: pravrajyā; C: chujia 出家, lit. "leaving home/family") meant leaving the world, with all of its social relationships and cultural norms, and adopting a celibate way of life centred on religious pursuits and humanitarian service. This created a gap between the monks and the laity - which encompassed the socio-political elites as well as the general populace - even though in actual practice Buddhist monasteries were in contact with their surrounding communities. In addition, often the monks' vocational work had social dimensions.

Despite their autonomy, in India (and elsewhere) monastic communities tended to lack financial independence and economic self-sufficiency. In large part, this was by design, as the Vinaya rules proscribed profit-oriented economic activity. Furthermore, the central monastic ideals, especially the emphasis on detachment and transcendence, were largely inimical to the pursuit of power and the accumulation of wealth. ${ }^{10}$ Nonetheless, the maintenance and growth of large monastic communities was not cheap. The building and upkeep of temples and monastic dwellings, the procurement of daily provisions for the community, and the meeting of other practical necessities all had to be taken care of. Consequently, monasteries relied heavily on lay donations, and also tended to seek state support. At times, they also sought to supplement those sources of income with overtly commercial activities, even if they were not necessarily in accord with the letter or the spirit of the Vinaya. ${ }^{11}$ The economic activities of Buddhist monasteries can even be seen as a form of religious "capitalism ", which evokes comparison with the growth of the Christian monastic economy in Europe during the Middle Ages. ${ }^{12}$

9 For surveys of the Vinaya, especially in the Indian context, see Holt, Discipline, and Prebish, Buddhist Monastic Discipline. For its East Asian adaptations, see Bodiford, Going Forth.

10 Of course, over the centuries many monks found ways to circumvent the assorted rules related to monastic simplicity and poverty, and sought ways to enrich themselves and their monasteries. As is the case with other religions, in Buddhism there was often a notable gap between professed religious ideals and lived reality.

11 For instance, see the survey of industrial installation and commercial activities undertaken by Chinese monasteries described in Gernet, Buddhism in Chinese Society, 142-191. For more on the monastic economy, see He, Fojiao siyuan jingji ji qi yingxiang chu tan.

12 Collins, Weberian Sociological Theory, 54-73. 


\section{Confucian-inspired critiques}

Within the Indian context there was a general acceptance, even exaltation, of nominally independent and self-governing religious orders like the Buddhist Sangha. Ascetics and renunciates of various kinds tended to be respected in Indian society, and their religious way of life was deemed to be worthy of public support and approbation. This contrasted with the situation that obtained in China at the time when Buddhism was first introduced via the Silk Road, even though the practice of reclusion - religious or secular - was not unknown in China. ${ }^{13}$ The growing presence of the foreign religion thus posed a serious challenge for the imperium and the ruling elites: how to incorporate a large institutional body such as the Sangha into China's all-encompassing and authoritarian system, in which the ruler supposedly had total control over everybody and everything. The situation was made even more difficult by the fact that in China there was no real precedent for the existence of independent religious orders or institutions.

The expanding presence of Buddhism in China elicited a range of responses, from passionate acceptance to outright rejection. Tensions or conflicts between Buddhism and the imperial bureaucracy developed gradually. Initially, Buddhism was primarily a religion of foreigners and minority groups, mostly from Central Asia, with a small footprint and limited impact on local society. The situation started to change from the end of the Han era onward - a period of political instability and social turbulence - as Buddhism become more popular and started to attract an increasing number of Chinese followers, who came from various social strata. During this period, for the first time Chinese states and societies had to deal with organized religious movements - which included religious Daoism, in addition to Buddhism - that were large in scale, with complex visions of life and the place of humanity within the larger scheme of things. In the case of Buddhism, this included the introduction of novel ideals and institutions that transcended the familiar patterns of kinship ties, local bonds, and social hierarchies. ${ }^{14}$

The growth of Buddhism prompted a backlash from within official circles, which is reflected in the sets of critiques articulated by Confucian scholars and ideologues. What were the Chinese elites to make of a new religion with an otherworldly orientation, and which seemed to be primarily concerned with the individual's salvation and transcendence of the mundane world? Could its clergy somehow be incorporated into the Chinese system, or did it pose a grave challenge to political stability that could perhaps lead to a breakdown of the rigid social order? Were the contours of Chinese culture flexible enough to be able to absorb or integrate an alien faith?

One type of exclusionary critique was to reject Buddhism on an ethnocentric basis, on account of its foreign (»barbarian«) origins. Since China had the most glorious culture and had its own great sages such as Confucius and Laozi, the argument went, what need was there for a strange new religion that worshipped a foreign deity? Instead of adopting the beliefs and practices of culturally inferior people, the Chinese were better served if they upheld and strengthened their own traditions, which within key circles of power tended to be primarily construed in a Confucian fashion. This kind of critique, with the xenophobic sentiments that underscored it, continued for many centuries, as can be seen from Han Yu's 韓愈 (768-824) 
famous anti-Buddhist diatribe, "Memorial on the Buddha's Bone“ (Jian ying fo gu biao 諫迎 佛骨表), which he presented to Emperor Xianzong 憲宗 (r. 805-820) in 819. ${ }^{15}$ Nonetheless, criticisms of this sort already lost some of their potency during the Northern and Southern Dynasties (386-589). During this period many of the Chinese states, especially in the North, were ruled by non-Chinese people, who tended to have less vested interest in perpetuating a narrow vision of cultural hegemony, like the one promoted by Confucian ideologues. ${ }^{16}$

The main line of critiques against Buddhism, however, was directed towards the monastic order, which was perceived to be at odds with the existing socio-political structure and prevalent cultural norms. Since they were without clear-cut analogues in the Chinese historical experience, monks and monasteries were perceived to be alien and potentially threatening to the established order. A particularly sore point was the monks' celibate lifestyle and their rejection of family ties. This led to the grave accusation of monks being unfilial, especially by failing to produce male offspring, thus contravening the deeply ingrained practice of ancestor worship. From a Confucian perspective, this was a major transgression because it directly challenged the family system, which according to the Confucian classics formed the basic foundation of social and political order. ${ }^{17}$

Monks and monasteries were also attacked on economic grounds. Buddhist establishments were accused of being economically burdensome, as monks did not engage in any kind of productive labour. Furthermore, they consumed valuable resources and were expensive to maintain, thereby placing an unjustifiable financial burden on the state and the general populace. To make matters worse, they received tax exemptions, with negative impact on the imperial treasury. Finally, there were criticisms influenced by political considerations. In a culture without clear notions about religious freedom and the separation of church and state (as we understand them today), the monks' drive for a semblance of autonomy was perceived as being incompatible with the basic tenets of imperial ideology, which centred around the aforementioned notion that "nothing/nobody is outside of the purview of emperor's power and authority.«

\section{Rapprochements}

Notwithstanding the trenchant critiques articulated by its adversaries and detractors, Buddhism managed not only to survive but to flourish in China. Even before the Sui 隋 (589-618) and Tang dynasties, widely considered to be the golden age of Buddhism - as well as the high point of Chinese civilization - Buddhism developed into the most popular and powerful religion in China. Among the major reasons for the broad acceptance of Buddhism, observable among all social classes but especially strong at the top, were the apparent relevance and attractiveness of Buddhist beliefs and practices. At a basic level, Buddhism was able to meet a wide range of deeply-felt religious needs, in part by adapting to the native ethos and responding resourcefully to the spiritual predilections and cultural horizons of expectation of various segments of the local population.

15 See Sources of Chinese Tradition, ed. de Barry and Bloom, 583; Hartman, Han Yü, 84-86; Kenneth Ch'en, Chinese Transformation of Buddhism, 268-269.

16 Ch'en, Buddhism in China, 145-183; Lewis, China between Empires, 205-206.

17 For the early Buddhist-Confucian debates regarding filial piety, see Guang, Buddhist-Confucian Controversy, 421425. 
The new elements brought by Buddhism, which greatly enriched Chinese life and drastically reconfigured the religious landscape, included popular forms of cultic worship centred on various Buddhas and bodhisattvas, ${ }^{18}$ which often had explicitly utilitarian undertones. At the other end of the religious and intellectual spectrums, rarefied philosophical reflections were written on the meaning of life and the nature of reality. The Buddhist clergy also presented an array of rituals and solemn observances, as well as diverse techniques of spiritual cultivation, including meditation. In addition, Buddhism brought novel forms of literary and artistic expression, which facilitated the development of new aesthetic sensibilities and provided fecund avenues for creative expression, as can be seen from the many striking examples of Buddhist art created during this period. ${ }^{19}$ This protracted developmental process culminated with the emergence of distinctive schools (or traditions) of Buddhism that were unmistakably Chinese, such as Chan, Huayan, and Tiantai, which before long were also transmitted to Korea and Japan. ${ }^{20}$

A key factor in the growth of Buddhism was the prudent negotiation of the political landscape, which involved a rapprochement with the imperial state and its bureaucratic apparatus. From the perspective of the Buddhist monks, they stood to benefit economically and politically if they could secure support from the state and the ruling elites. But at a more basic level, they had little choice but to adapt to the existing power structures, and take advantage of whatever exemptions they could secure from the totalitarian regimes that ruled China. ${ }^{21}$ Becoming a target of imperial wrath, prejudice, or violence was something they could ill afford, as evidenced by the devastating anti-Buddhist persecutions they suffered several times under hostile monarchs determined to wipe out the religion (and appropriate the monastic wealth). Prime examples include the persecutions undertaken by Emperor Wudi 武帝 (r. 561578) of the Northern Zhou 北周 dynasty (557-581) during the 574-577 period, and Emperor Wuzong 武宗 (r. 840-846) of the Tang dynasty during the 842-845 period. ${ }^{22}$

From the point of view of the emperors and the ruling class, the reasons behind their support (or tolerance) of Buddhism were varied. At a basic level, many of them found that, if used prudently, Buddhism could be a potent tool of political legitimization that could bolster their hold on power. This became even more meaningful after the collapse of the Han order in 220 CE. During the subsequent centuries of political division, many non-Chinese monarchs ruled over ethnically diverse populations, which tended to be predominantly Han Chinese. In this new world there was less fixation on Confucian orthodoxy, along with greater cultural openness and receptiveness to different philosophies or alternative value systems.

18 The bodhisattva ideal is at the core of Mahāyāna, the dominant form of Buddhism in China and the rest of East Asia. The bodhisattvas can been understood as celestial beings with great wisdom and power, or as advanced practitioners who pursue the supreme path to the realization of Buddhahood. In a second sense, everybody can aspire to be a bodhisattva.

19 See Poceski, Introducing Chinese Religions, 119-132, 144-48; Poceski, Chinese Buddhism, 207-216; Poceski, Buddhism in Chinese History, 53-56.

20 Poceski, Introducing Chinese Religions, 148-160.

21 For the methods used to control and manage the monastic order, see Bai, Tang dai de sengji guanli zhidu.

22 For more details about the persecutions, see Ch'en, Buddhism in China, 190-194, 226-33; Weinstein, Buddhism under the T'ang, 114-135. 
Monks could become useful to the existing power structure by performing various rituals on behalf of the ruler and the dynasty, thereby securing blessings and divine support for their imperial patrons. In due course, this gave rise to "state protection Buddhism" (huguo fojiao 護國佛敉). ${ }^{23}$ There were also monks who attracted attention and a following by their supposed ability to perform miracles, which resonated among the elites as well as the general populace. ${ }^{24}$ Another important factor that contributed to the fortunes (or misfortunes) of Buddhism was the personal piety of individual rulers. If an emperor turned out to be an enthusiastic devotee or follower of the Buddhist teachings, he could extend various forms of financial and political support to the religion, including the granting of exemptions to the monastic order. A prime example of this is Emperor Wu of the Liang dynasty 梁武帝 (r. 502549), who during his long reign became well-known for his personal piety and extravagant support of individual monks and Buddhist institutions. ${ }^{25}$

\section{Exemptions}

As part of the ongoing efforts at carving a suitable space for Buddhism and incorporating the monastic order into the social fabric and political structures of China, various imperial governments gave certain exemptions to individual monks and monasteries. One such exemption - release from the obligation to engage in a ritual action that demonstrates obedience to the ruler - is discussed in more detail in the next two sections. To provide additional context, here I briefly survey some of the other exemptions that were granted - as well as taken away - to members of monastic orders. These included exemptions from taxation (either of individual monks or of monastic lands and estates), military conscription, and compulsory labour service (or corvée, levied to commoners and often involving public projects such as building roads, military fortifications and irrigation canals, or clearing of new lands).

Generally, monks and nuns were exempt from personal taxes, military conscription, and compulsory labour services imposed by the state. There were specific legal provisions that dealt with these issues, and later dynasties tended to look to earlier ones for precedents. During most of the medieval period, the names of individual monastics were not added to the regular household registers used for the assessment of taxes, which were part of the official census compiled by the government. While monks and nuns were required to register with governmental authorities, their names were added to a separate register of monastics (seng $j i$ 僧籍). ${ }^{26}$

23 Some Buddhists composed apocryphal scriptures that asserted the potency of Buddhism in fulfilling that role. A prime example is the Perfection of Wisdom Scripture for Humane Kings' Protection of their States (仁王護國般若波羅 蜜經), T 8, no. 246. For a study and translation, see Orzech, Politics and Transcendent Wisdom.

24 Zürcher, Buddhist Conquest of China, 145-147; Poceski, Records of Mazu, 62-68; Robert Ford Campany, Signs from the Unseen Realm.

25 For Emperor Wu and Buddhism, see Makita, Chūgoku Bukkyōshi kenkyū, 215-234; Strange, Representations of Liang Emperor Wu, 124-128.

26 Ch'en, Chinese Transformation of Buddhism, 136. 
The exemptions granted by the state to the monastic order are noted in a number of primary sources, secular and Buddhist. Below is an example from the Yuan dynasty (12791368), from a Chan monastic code that belongs to the "rules of purity « (qinggui 清規) genre. The text in question is Chixiu baizhang qinggui 勅修百丈清規 (Imperial Edition of Baizhang's Rules of Purity), compiled by Dongyang Dehui 東陽德輝 in 1338. The quoted passage appears at the very beginning of the code, which highlights the importance monks attached to the relationship between the state and the monastic order. This influential code includes much earlier material, and on the whole it exemplifies common views and conventional practices prevalent in late imperial China.

\section{人之所貴在明道。故自古聖君崇吾西方聖人之教。不以世禮待吾徒。尊其道也。欽惟國 朝優遇尤至。特酤賦役使安厥居。而期以悉力于道。聖恩廣博天地莫窮。 \\ What the people value is the realization of the Way. Therefore, since ancient times the sagely monarchs (of China) have honoured the teachings of our Western Sage (the Bud- dha). They have not subjected us, the Buddha's disciples, to the worldly norms of pro- priety. (This is the case because) they revere the Way. With respectful deliberation, the present imperial court has extended preferential treatment (to Buddhist monks) in a most outstanding manner. (Buddhist monks have been given) special exemptions from taxation and labour service, enabling them to peacefully reside (in their monasteries). That way, they are expected to extended all their energy towards (pursuit of) the Way. The imperial grace is as vast as heaven and earth, and is impossible to exhaust. ${ }^{27}$}

The text then goes on to explain that monks must repay their indebtedness to the imperial throne (bao jun 報君), primarily by staying true to their vocation. A noteworthy feature in this passage - also found in other texts - is the acknowledgement that the exemptions from taxes and labour service are special favours extended to the Sangha by the (supposedly) benevolent imperial government. At a basic level, the relationship between the two sides is not that of equals, as the government clearly has the upper hand. Since these exemptions are special favours rather than undeniable rights, presumably they can be revoked at any time by the state, which in the end has the final say in this (and other) matters. On the other hand, it is also true that if the government came too strongly against the monastic order, it risked alienating many of its supporters and sympathizers, who typically included members of the government's officialdom as well as large segments of the general population.

The basic assumption underlying these exceptions was that monks formed a different class of people, who had abandoned kinship ties and left society for a life dedicated to spiritual pursuits. Having left the mundane world of human relations, monks were not to be subjected to the same regulations and obligations as the general population. The recognition of a clear-cut difference between monastics and the laity, along with the affirmation of a special legal and social status that was tied up with it, were widely accepted in medieval China. Nonetheless, they did not go uncontested. In fact, they were challenged on numerous occasions, typically by rulers or officials with Confucian leanings or negative feelings towards Buddhism. The passage below illustrates such anti-clerical attitudes. This critique of monastic waywardness and delinquency is articulated by Huan Xuan 桓玄 (369-404), the warlord who appears again in the next section.

27 T 48.1112c20-24; translation loosely adapted from the Baizhang Zen Monastic Regulations, trans. Ichimura, 3. 
京師競其奢淫。榮觀紛於朝市。天府以之傾匱、名器為之穢黷。避役鍾於百里、逋逃盈 於寺廟。乃至一縣數千猥成屯落。

The monks in the capital (seem to) compete with each other in terms of their extravagance and depravity. Their ostentatious appearance can be seen everywhere at the royal court and in the cities. The imperial treasury is exhausted because of them, while the normal order of society is defiled and dishonoured by them. Those who avoid compulsory labour service crowd around together, coming from (as far as) a hundred miles, while those who evade taxes fill the monasteries and the temples. It has gone even as far as having thousands of them within a single district, forming (what is tantamount) to villages. ${ }^{28}$

This kind of critique or challenge to monastic exemptions was often influenced by specific concerns or circumstances. For instance, in 577 there was a call for monks to sign up for military service because of a shortage of troops to deal with fighting taking place in an area covered by the present-day provinces of Anhui and Henan. ${ }^{29}$ Similar proposals were also made several decades later, during the early years of the Tang dynasty, as recorded by Daoxuan 道宣 (596-667) in his Guang hong ming ji 廣弘明集 (Expanded Collection of Texts about the Promotion of Clarity). Then Fu Yi 傅奕 (554-639), a conservative official in the Tang government, suggested that monks should be rounded up and forced to form army units. ${ }^{30} \mathrm{Fu} \mathrm{Yi}$, who was well known for his animosity towards Buddhism, wrote a number of anti-Buddhist memorials that called for the suppression or eradication of the religion, which sparked debate at the capital. ${ }^{31}$

The basic notion that the monastic exemptions could be given or withheld by the ruling regime, in accord with time and circumstance, underscored the prevalence of state control over the monastic order and the religion as a whole. In medieval China, even monastic ordinations were typically controlled by the state, which asserted its right to decide who could join the monastic order. In order to be officially considered a properly ordained monk, an individual had to receive an ordination certificate (jiedie 戒牒) issued by the government. ${ }^{32}$ In theory, those receiving ordination were expected to possess proper religious motivation and lead pious lives governed by the monastic rules and other pertinent customs. However, the state's control of ordinations, coupled with the fact that the tax and labour exemptions that came with monastic status were attractive to many with little or no religious motivation, had unintended consequences, often with a negative impact on the make-up, functioning, and reputation of the monastic order.

A persistent problem in medieval China (which continued during later periods) was that the privileges granted to monks attracted all sorts of characters with questionable backgrounds and dubious motives. Many individuals "joined « a monastic order primarily or solely in order to receive ordination certificates, which would enable them to obtain tax-exempt

28 Hong ming $j i$ 弘明集 12, T 52.85a17-20. The translation is loosely adapted from Zürcher, Buddhist Conquest of China, 260. See also Ch'en, Chinese Transformation of Buddhism, 92.

29 Gernet, Buddhism in Chinese Society, 32.

30 Guang hong ming ji 7, T 52.134c4-7. Also cited in Gernet, Buddhism in Chinese Society, 33. See also the discussion of Fu Yi in fascicle 13 of Guang hong ming ji.

31 See Twitchett, Cambridge History of China, 180; Weinstein, Buddhism under the T'ang, 7-8.

32 For the ordination certificates and the registration of monks, see Yifa, Origins of Buddhist Monastic Codes in China, 75-78. 
status and avoid work service. ${ }^{33}$ The presence of such fake monks swelled the official ranks of the monastic order, while reducing the number of adults subject to taxation. Predictably, this alarmed many officials in the government, some of whom presented memorials (official documents presented to the emperor) that criticized the granting of exemptions. ${ }^{34}$ This kind of situation was an important factor behind the occasional purges of the monastic orders undertaken by the government, although usually there were other issues at play as well.

At the same time, the government often made the situation worse by some of the questionable ways by which it determined the allocation of ordination certificates. On a number of occasions, the certificates were put up for sale to whoever could afford them, with the revenue going to the government's coffers. Predictably, many who took the government on its offer were rich layman intent on dodging taxes. Such policies were short-sighted, in as much as they reduced the tax base and created fiscal problems further down the road. But often they were irresistible, as they enabled the authorities to raise large amounts of revenue within a short timeframe. A pertinent example is the sale of ordination certificates during the An Lushan 安祿山 rebellion (755-763), to which the cash-strapped central government resorted as a desperate measure to raise revenue. ${ }^{35}$ But such lucrative sales were also undertaken at times when there was less political urgency or fiscal distress. Furthermore, they were abused by corrupt local officials, who used proceeds from the sales to enrich themselves.

There were also various problems related to the tax-exempt status of monastic lands and other properties. This were not granted as often or as readily as was the case with the tax exemptions extended to individual monks and nuns. In general, this kind of tax exemption was usually granted only to monasteries that received imperial patronage or were officially recognized by the state. While it brought undeniable economic benefits to those monasteries, the granting of such tax privileges also opened the door for various sorts of shady dealings and dubious practices. This included tax-dodging schemes in which wealthy landowners "donated « their land to monasteries in order to shelter it from taxes. ${ }^{36}$

\section{Huiyuan and his treatise}

One of the best-known debates about the granting versus the withholding of specific exemptions for monastics took place in 402, during what was still a formative period in the history of Buddhism in China. The debate centred on a seemingly innocuous or symbolic issue: should monks be required to pay ritual obeisance to the ruler, as was expected of all imperial subjects? The main person making the Buddhist case - against the motion to deny the exemption - was Huiyuan, widely considered to be among the most influential monks during the early centuries of Buddhism's growth in China. ${ }^{37}$ Huiyuan joined the ongoing debate, which initially developed at the imperial capital, from his monastic retreat at Lushan 盧 山, located in the southern part of the empire.

Gernet, Buddhism in Chinese Society, 38-40, 42. Bukkyōshi kenkyū, 144-146.

37 For Huiyuan's monastic biography, see Gao seng zhuan 高僧傳 6, T 50. 357c23-61b13; also translated in Zürcher, Buddhist Conquest of China, 240-253. 
According to his biographical entry in Gao seng zhuan 高僧傳 (Biographies of Eminent Monks), compiled in 519 by Huijiao 慧晈 (497-554), during his youth Huiyuan received a classical education, having studied the Confucian classics as well as important Daoist texts such as Laozi 老子 and Zhuangzi 莊子. ${ }^{8}$ While still a young man, he decided to leave the mundane realm and become a Buddhist monk. His monastic teacher was Daoan 道安 (312385), arguably the most prominent and influential Buddhist leader of the time. Although originally a northerner, later in life Huiyuan moved south and settled at Lushan, the famous scenic mountain in Jiangxi. There he became a leader of a flourishing monastic community, centred at Donglin monastery 東林寺, which he established in the 380s. Although Huiyuan remained at his mountain monastery until his death in 416 , his fame spread far and he came to be perceived as one of the foremost clerics in China.

Huiyuan was a person of varied talents and wide-ranging interests. Within and outside the Buddhist community, he was renowned for his compelling personality and respected as a charismatic leader who embodied cherished monastic ideals. The monastic regimen of doctrinal study, contemplative practice, ritual performance, and ethical observance he instituted at his monastery at Lushan became a model for monastic establishments in other parts of China. He is especially associated with the development of the Pure Land tradition in East Asia. In large part that is due to his establishment of a fellowship of committed practitioners - including both monks and laymen - who dedicated themselves to devotional and contemplative practices directed towards the attainment of rebirth in Sukhāvatī, the pure land of Amitābha Buddha.

Huiyuan's main opponent in the debate was Huan Xuan, the warlord quoted in the previous section. He was a military man during the Jin 晉 dynasty (265-420), and a son of Huan Wen 桓溫 (312-373), the grand marshal of Jin and one of the greatest generals in fourth century China. Huan Xuan briefly came to usurp the throne, and in 403 he established a new dynasty named Chu 楚. His reign was very short-lived, however, as he was assassinated in 404 . Soon after his occupation of the Jin capital in 402 and his seizure of dictatorial power, Huan Xuan started to initiate policies intended to curb the influence of Buddhism and reduce the size of the monastic order. This included a demand that monks should pay ritual obeisance to the ruler, ${ }^{39}$ which elicited Huiyuan's famous response discussed in the next section. It is interesting to note that it was Huan Xuan himself who invited Huiyuan to join the debate, presumably because of Huiyuan's impeccable reputation and lofty stature.

Huiyuan's main line of reasoning and his arguments against Huan Xuan's anti-Buddhist stance and restrictive policies are preserved in the form of a polemical treatise titled Shamen bujing wangzhe lun 沙門不敬王者論 (Treatise on Monks not Venerating the Ruler). ${ }^{40}$ The treatise is based on a letter that Huiyuan sent to Huan Xuan, in response to the dictator's

38 Gao seng zhuan 6, T 50.357c24-27.

39 Zürcher, Buddhist Conquest of China, 155-157, 231-239; Ch'en, Buddhism in China, 76-77.

40 For examples of modern articles that deal with Huiyuan's treatise and the controversy that inspired it, see Zhou, Huiyuan shamen bu jing wangzhe lun de lilun jichu; Gu, Dongjin jingwang zhi zheng kao ping. 
request that Huiyuan present his views on the pro- and anti-Buddhist polemics that were raging in the capital. The entire treatise is preserved in fascicle five of Hong ming ji 弘明集 (Collection of Texts about the Promotion of Clarity), compiled by Sengyou 僧佑 (445-518). ${ }^{41}$ This large text (in fourteen fascicles) contains a wealth of information about the various antiBuddhist discourses and polemics that unfolded during the fourth to early sixth century. It also contains a range of Buddhist responses to such criticisms, along with records that testify to the vigorous efforts of prominent monks and lay supporters to promote the teachings and practices of Buddhism. An abbreviated version of the treatise (or rather a brief outline) is also included in Huiyuan's biography in Gao seng zhuan. ${ }^{42}$ Moreover, its contents are reproduced, summarized, or discussed in later texts, such as Ji shamen buying bai su deng shi 集沙門不應 拜俗等事 (fascicle two), which contains the whole text, ${ }^{43}$ and Fozu tongji 佛祖統紀 (fascicle twenty-six), which only has a short outline. ${ }^{44}$

\section{Huiyuan's arguments}

On the surface, the debate about whether monks should pay ritualized homage to the emperor seems to revolve around a largely symbolic issue. Nonetheless, there was much at stake, as the ritual act of bowing to the emperor was emblematic of key power relations and social hierarchies, and reflected larger philosophical and political issues. This was not really a new topic of discussion, as there had been a similar debate in 340, during the Eastern Jin 東晉 dynasty (317-420). At that time, during the reign of Chengdi 成帝 (r. 325-342), Yu Bing 座 冰 (296-344), a powerful aristocrat, proposed that the Buddhist clergy should show its subservience to the throne by bowing to the ruler. The Buddhist opposition at the time was led by He Chong 何充 (292-346), a Buddhist layman and high official in the central government, who vehemently disagreed with the anti-Buddhist proposal. After official deliberations at the imperial court, the pro-Buddhist arguments prevailed..$^{45}$

In essence, the debate was about the relationship between the monastic order and the imperial state - personified by the emperor - as well as the degree of supremacy and control that the government had over the religion. The basic power and authority of the emperor (and the government) were not really in question, as they were accepted as normative by all parties. The main issue to be adjudicated was whether monks, as a distinct group or class in medieval society, were different enough from other imperial subjects to warrant special permission to deviate from established norms of ritually appropriate behaviour. More broadly, it was about granting the monastic order a distinct status, perhaps even a semblance of autonomy, within the confines of the autocratic state.

41 T 2102, vol. 52. For a translation of the first seven fascicles, see, Collection for the Propagation and Clarification of Buddhism, trans. Ziegler. For a modern Chinese translation, see Lu, Huiyuan fashi shamen bu jing wangzhe lun wu pian bing xu jin yi.

42 T 50.360c18-361a10.

$43 \mathrm{~T}$ 52.449a2-451b10. This text also contains a wealth of related materials, including letters, edicts, and memorials written by Huiyuan, Huan Xuan, and various officials.

44 T 49.262a29-c5.

45 See Ch'en, Chinese Transformation of Buddhism, 69-71; Zürcher, Buddhist Conquest of China, 106-110. 
Huiyuan's treatise is divided into five sections. The first two detail the different aspirations and lifestyles of laypeople and monks, respectively. The third section describes the monks' search for ultimate truth and release from the bonds of samsara, the cycle of birth and death. The fourth section presents a response to a counterargument: an imaginary opponent contends that there is no higher truth than what has been revealed in the past by the great sages of China. The last section contains a somewhat abstract - and from a purely doctrinal perspective, not very sophisticated - argument about the Buddha as an immortal spirit, who permeates the everyday world of phenomenal appearances but is still separate from it. What follows is a short outline of some of the main parts of the treatise, accompanied with translations of several relevant passages, taken from the abbreviated version included in Huiyuan's biography in Gao seng zhuan. ${ }^{46}$

Huiyuan begins his treatise with a discussion of Buddhist laypeople and their role in society. He is careful to point out that they are not different from other imperial subjects. They follow all secular laws and worldly customs, and in no way do they shy away from their duties towards the ruler, including the performance of appropriate rituals and the showing of utmost respect. At a basic level, the Buddhist laity do not pose any danger to the socio-political status quo, nor do they challenge the authority of the ruler and the imperial state.

\section{一日在家。謂在家奉法、則是順化之民。情未變俗、迹同方內。故有天屬之愛、奉主之 禮。禮敬有本、遂因之以成教。 \\ First, there are the laypeople. As householders, they follow the laws (of the state) and are (deferential) subjects who obey (the ruler). Without deviating from common customs and established norms, they act in accordance with existing rules. Consequently, they possess the (natural) love (that should be manifested) towards one's kin, and observe the rites that show deferential respects towards the ruler. On the basis of reverence and ritual, they become civilized individuals. ${ }^{47}$}

In the second section, Huiyuan goes on to describe the way of the religious and highlights the monastic distinction. Unlike the laity, he argues, monks have left society and do not follow normal patterns of behaviour, including the outward manifestation of filial piety and the ritualized showing of respect towards the ruler. Nonetheless, they do so for a lofty purpose: to plumb the depths of reality and transcend the everyday realm of suffering and imperfection. While their religious way of life precludes their participation in mundane activities, by realizing the goals of the Buddhist path monks bring real benefits to society. Moreover, in a deeper sense, the genuine pursuit of their vocation does not really contravene the basic (Confucian) principles of filial piety and reverence for the ruler.

46 For a translation of Huyuan's treatise, see Hurvitz, 'Render unto Caesar` in Early Chinese Buddhism.

47 Gao seng zhuan 6, T 50.360c19-22. Cf. Zürcher, Buddhist Conquest of China, 251. 
二日出家。謂出家者、能遁世以求其志。變俗以達其道。變俗則服章不得與世典同禮。 遁世則宜高尚其迹。大德故能拯溺俗於沈流、拔玄根於重劫。…如令一夫全德、則道洽 六親澤流天下。雖不處王侯之位、固已協契皇極在宥生民矣。是故內乘天屬之重、而不 逆其孝。外閲奉主之恭、而不失其敬也。

Second, there are the monks (lit. »those who have left home/family«). Monks are able to leave the (secular) world in order to pursue their (spiritual) aspirations. They do not follow social conventions, so that they can realize the Way. Having abandoned social conventions, their robes do not accord with the rules of propriety prescribed in the secular classics. Having left the (secular) world, they are obliged to act in a lofty manner. Monks of great virtue are able to save a sinking world from drawing into the stream (of samsara, or the cycle of birth and death), as well as pull out the mysterious root (of bad karma accumulated over) recurring eons. ... Even if only a single monk were to attain perfect virtue, then the (true) Way will extend to the six close relations and its benefits will spread throughout the world. ${ }^{48}$ Although he does not assume the position of royalty, such a person assuredly contributes to the empire's efforts to benefit the common people. Therefore, although inwardly (monks) turn their back to the natural feelings (of emotional attachment) towards their kin, they do not betray (the virtue of) filial piety. Outwardly, although they do not show the (conventional) form of respect due to the monarch, they do not violate (the virtue of) reverence. ${ }^{49}$

In the next section, titled "Those who seek the ultimate purport do not follow the ways of the world “ (求宗不順化), Huiyuan builds upon his argument about the monastic distinction by elaborating on the monks' lofty ideals, and by reiterating the great significance of their spiritual quest for the transcendence of Nirvana. Given that monks seek to go beyond the limitations of the mundane realm, they cannot be burdened with worldly sentiments or commonplace expectations. Furthermore, because of the intrinsic worthiness of their aspiration, monks deserve high respect and special status in society.

故沙門雖抗禮萬乘、高尚其事。不爵王侯、而沾其惠者也。

Therefore, although monks (śramana) behave towards the emperor as if they were his equals, their conduct is virtuous. While they are not given noble titles such as prince or marquis, they are still recipients of (imperial) favours..$^{50}$

In the final two sections - the longest in the treatise - Huiyuan moves somewhat off topic, to deal with larger issues related to Buddhist doctrine and its relationship with Chinese traditions. This is especially true of the last section, where the central topic of discussion is the immortality of the soul. Because of this, and due to space limitations, I will not deal here with these two sections. But it is perhaps worth mentioning that in the fourth section Huiyuan presents a familiar set of arguments about the essential compatibility of Buddhism and Confucianism. While there are notable differences in the doctrines of the two traditions, he contends, their aims are essentially the same and they lead to the same goal..$^{1}$

48 The six close relations are those of father, mother, elder brother, younger brother, wife, and son.

49 Gao seng zhuan 6, T 50.360c22-361a1. Cf. Zürcher,Buddhist Conquest of China, 251.

50 Gao seng zhuan 6, T 50.361a5-6. Cf. Zürcher, Buddhist Conquest of China, 252.

51 For the last two sections, see Hurvitz, "Render unto Caesar« in Early Chinese Buddhism, 103-114. 
Apparently Huiyuan's arguments proved persuasive, as Huan Xuan abandoned his original plan to purge the monastic order and force its members to pay him obeisance. Nonetheless, this did not put an end to the larger debate about this and other monastic exemptions, and more broadly about the relationship between the state and the Buddhist order. For instance, in 606 Emperor Yang 煬帝 (r. 604-618) of the Sui dynasty - on the whole, a period of great flourishing for Buddhism - ordered a reassessment of the same exemption, as part of a broader effort to gain greater control over the monastic order. ${ }^{52}$ Similarly, in 662 Emperor Gaozong 高宗 (r. 649-683), the third monarch of the Tang dynasty, issued a decree ordering monks to pay ritual obeisance to both their parents and the emperor. ${ }^{53}$

The anti-Buddhist measure proposed by Gaozong followed an edict issued five years earlier, in which he forbade monks to receive homage from their parents. After vigorous debate at the capital, which involved the participation of numerous court officials, aristocrats, and prominent monks such as Daoxuan, the emperor decided on a compromise solution: the traditional exemption from paying ritual homage to the emperor was reaffirmed, but monks were asked to kneel before their parents, as an expression of filial piety. After encountering further vocal opposition, the emperor decided to rescind that decree as well, although that still did not put the whole issue to rest. ${ }^{54}$

\section{Concluding remarks}

In general, over the centuries the centralized state(s) made some adjustments that made it possible to incorporate Buddhism into China's socio-political structures. This in turn made it possible for the religion to take firm root in Chinese soil and become a major factor in the social and cultural spheres. Nonetheless, the state never really gave up on the core ideological principles - largely based on Confucian texts and traditions - that underpinned its exercise of total control and absolute authority. While the general political climate and specific state policies varied somewhat from one dynastic period to another, on the whole the various rulers and their imperial bureaucracies pursued policies aimed at controlling, co-opting, and exploiting Buddhism and other religions in ways that ultimately benefited the state and enhanced its grasp of power. ${ }^{55}$ In that sense, Buddhist monks and other religious were never able to enjoy a free exercise of religious belief and practice. By extension, the relationship between the state and the Buddhist order was never one of equals, as the state ultimately wielded complete political power and could exert control over all facets of Chinese life, including religion.

52 Xiong, Emperor Yang of the Sui Dynasty, 167-168.

53 Weinstein, Buddhism under the T'ang, 32-33; Ch'en, Chinese Transformation of Buddhism, 78-80. For the text of the original edict, see Quan tang wen 全唐文14.66c.

54 Weinstein, Buddhism under the T'ang, 34. As noted by Weinstein, the debate continued to resurface on and off for another century.

55 Yu, State and Religion in China, 3-4. 
Buddhism presented perhaps the strongest challenge to the existing order, as its basic doctrines and practices were not necessarily in tune with native norms and entrenched values. This engendered various tensions and discords, which had to be addressed by ongoing negotiations and adjustments. ${ }^{56}$ The formative growth of Buddhism in China was helped by the relatively open attitudes that prevailed during the centuries of political disunion, which created peculiar historical circumstances that were favourable to the establishment of a new faith transmitted from foreign lands. However, in the end the monastic order lost the struggle for religious freedom, and had to come to terms with the prevailing imperial ideology and accede to the state's supremacy. ${ }^{57}$ The general historical pattern was to exert increasing control and to co-opt monastic institutions by incorporating them into the social, political, and economic structures regulated by the autocratic state.

By and large, Buddhist monks ended up being allied with the Chinese state, although there were some who withdrew into seclusion and avoided political involvement. Virtually none of them pursued the third option available to religious groups: to engage in active struggle with the political establishment, and to try to challenge the status quo by becoming politically active or dominant. ${ }^{58}$ In China that sort of revolutionary activity was occasionally pursued by marginal religious groups and popular movements - labelled heresies or evil cults, in official parlance. Buddhism and other major religions were basically drafted into becoming part of the mainstream establishment, while occupying a subservient position visà-vis the state.

By looking at some of the specific religious milieus and historical contexts of medieval China, including the professed pieties of individual monarchs and the political predicaments they faced, this article indirectly points to interesting parallels between the situations that obtained in China and elsewhere, especially Christian Europe. At the same time, its analysis also calls for a critical reassessment of some of the central concepts and entrenched paradigms that often guide scholarly and popular discussions about church versus state relations. More specifically, the materials presented here problematize the basic religious-secular dichotomy, especially the supposed opposition that pitted the church (here represented by Buddhism) against the secular state (represented by the various Chinese empires that rose and fell during the medieval period).

Notwithstanding the many fascinating parallels with important historical developments in Europe and the Middle East, Buddhism does not quite neatly fit into the established category of religion (narrowly defined), which is largely constructed in terms of Eurocentric models and conceptions. In the same vein, setting aside the one-sided (and largely misleading) narrative promoted by Confucian ideologues (and their sympathizers), on the whole the premodern Chinese state was hardly secular, or narrowly Confucian. Much like the modern communist government, the imperial state was religiously obsessed with its own political power and absolute authority, ${ }^{59}$ which were repeatedly asserted with dogmatic conviction and guarded by whatever means necessary, including ideological posturing, blatant propaganda, and brute force.

$56 \mathrm{Yu}$, State and Religion in China, 92.

57 Ch'en, Chinese Transformation of Buddhism, 124.

58 For these responses to the state's control over religion, see Yang, Religion in Chinese Society, 105.

59 Yu, State and Religion in China, 145.

medieval worlds $•$ No. $6 \cdot 2017 \cdot 40-60$ 


\section{References}

$\mathrm{T}$ = Taishō shinshū daizōkyō 大正新修大藏經. Compiled under the direction of Takakusu Junjirō 高楠順次郎 and Watanabe Kaikyoku 渡邊海旭. Vols. 1-85. Issaikyō kankōkai 一切經刊 行會 (Tokyo, 1924-1932).

Adshead, Samuel Adrian M., T'ang China: The Rise of the East in World History (New York, 2004).

Bai Wengu 白文固, Tang dai de sengji guanli zhidu 唐代的僧籍管理制度. Pumen xue bao 普門 學報 15 (2003) 1-20.

The Baizhang Zen Monastic Regulations, trans. Shohei Ichimura (Berkeley, 2006).

Berkowitz, Alan J., Patterns of Disengagement: The Practice and Portrayal of Reclusion in Early Medieval China (Stanford, CA, 2000).

Bodiford, William M. (ed.), Going Forth: Visions of Buddhist Vinaya (Honolulu, 2005).

Campany, Robert Ford, Signs from the Unseen Realm: Buddhist Miracle Tales from Early Medieval China (Honolulu, 2012).

Ch'en, Kenneth, Buddhism in China: A Historical Survey (Princeton, 1964).

Ch'en, Kenneth, The Chinese Transformation of Buddhism (Princeton, 1973).

The Collection for the Propagation and Clarification of Buddhism, trans. Harumi Hirano Ziegler (Berkeley, 2015).

Collins, Randall, Weberian Sociological Theory (Cambridge, 1986).

Dewaraja, Lorna, Buddhist Women in India and Precolonial Sri Lanka, in: Karma Lekshe Tsomo (ed.), Buddhist Women across Cultures: Realizations (Albany, 1999) 67-78.

Feuchtwang, Stephen, Popular Religions in China: The Imperial Metaphor (Richmond, Surrey, 2001).

Gernet, Jacques, Buddhism in Chinese Society: An Economic History from the Fifth to the Tenth Centuries (New York, 1995).

Gu Weikang 顧偉康, Dongjin jingwang zhi zheng kao ping 東晉敬王之爭考評, Fagu foxue xue bao 法鼓佛學學報 11 (2012) 97-122.

Guang Xing, A Buddhist-Confucian Controversy on Filial Piety, Journal of Chinese Philosophy 37/2 (2010) 248-260.

Hansen, Valerie, Changing Gods in Medieval China, 1127-1276 (Princeton, 1990).

Hartman, Charles, Han Yü and the T'ang Search for Unity (Princeton, 1986).

He Rong 何蓉, Fojiao siyuan jingji ji qi yingxiang chu tan 佛教寺院經濟及其影響初探, Shehui xue yanjiu 社會學研究 4 (2007) 75-92.

Hirakawa, Akira, and Groner, Paul, A History of Indian Buddhism: From Sākyamuni to Early Mahāyāna (Honolulu, 1990).

Holt, John, Discipline: The Canonical Buddhism of the Vinayapitaka (Delhi, 1981).

Hurvitz, Leon, >Render unto Caesar` in Early Chinese Buddhism: Hui-yuan's Treatise on the Exemption of the Buddhist Clergy from the Requirements of Civil Etiquette, Sino-Indian Studies 5/3-4 (1957) 96-114.

Gentz, Joachim. Long Live the King! The Ideology of Power between Ritual in Morality in the Gongyang Zhuan, in: Yuri Pines, Paul R. Goldin and Martin Kern (eds.), Ideology of Power and Power of Ideology in Early China (Brill, 2015) 69-117.

Lewis, Mark Edward, China between Empires: The Northern and Southern Dynasties (Cambridge, Mass., 2009). 
Lu Youxiang 吕有祥, Huiyuan fashi shamen bu jing wangzhe lun wu pian bing xu jin yi 慧遠 法師沙門不敬王者論五篇并序今譯. Retrieved on 3 December 2017: http://read.goodweb. cn/news/news_view.asp?newsid=78054.

Makita, Tairyō, 牧田諦亮, Chūgoku Bukkyōshi kenkyū 中国仏教史研究 (Tōkyō, 1981).

Meeks, Lory, Nuns and Laywomen in East Asian Buddhism,in: Mario Poceski (ed.), The Wiley Blackwell Companion to East and Inner Asian Buddhism (Oxford, 2014) 318-339.

Mizuno, Kōgen, The Beginnings of Buddhism (Tokyo, 1980).

Orzech, Charles D., Politics and Transcendent Wisdom: The Scripture for Humane Kings in the Creation of Chinese Buddhism (University Park, PA, 2008).

Poceski, Mario, Buddhism in Chinese History, in: Mario Poceski (ed.), The Wiley Blackwell Companion to East and Inner Asian Buddhism (Oxford, 2014) 40-62.

Poceski, Mario, Chinese Buddhism, in: Randall Nadeau (ed.), The Blackwell Companion to Chinese Religions (Oxford, 2012) 197-218.

Poceski, Mario, Introducing Chinese Religions (New York, 2009).

Poceski, Mario, The Records of Mazu and the Making of Classical Chan Literature (Oxford, 2015).

Pan, Yihong, Son of Heaven and Heavenly Qaghan: Sui-Tang China and Its Neighbors (Bellingham, 1997).

Prebish, Charles S., Buddhist Monastic Discipline: The Sanskrit Prätimokșa Sütras of the Mahāsāmghikas and Mūlasarvāstivādins (University Park, PA, 1975).

Quan tang wen 全唐文 (1814), compiled by Dong Gao 董誥, et al. (1) Shanghai: Shanghai guji chubanshe, 1990; (2) Taipei: Huawen shuju, 1961; (3) Beijing: Zhonghua shuju, 1985.

Sources of Chinese Tradition: From Earliest Times to 160o, ed. William Theodore de Bary and Irene Bloom (New York, 1999).

Strange, Mark, Representations of Liang Emperor $\mathrm{Wu}$ as a Buddhist Ruler in Sixth- and Seventh-century Texts, Asia Major 24/2 (2011) 53-112.

Twitchett, Denis (ed.), Cambridge History of China, Vol. 3: Sui and T'ang China 589-906, Part 1 (Cambridge, 1979).

Weinstein, Stanley, Buddhism under the T'ang (Cambridge, 1987).

Wijayaratna, Môhan, Buddhist Monastic Life: According to the Texts of the Theravāda Tradition (Cambridge, 1990).

Xiong, Victor Cunrui, Emperor Yang of the Sui Dynasty: His Life, Times, and Legacy (Albany, 2006).

Yang, Ch'ing-k'un, Religion in Chinese Society: A Study of Contemporary Social Functions of Religion and Some of Their Historical Factors (Berkley, 1970).

Yifa, The Origins of Buddhist Monastic Codes in China: An Annotated Translation and Study of the Chanyuan Qinggui (Honolulu, 2002).

Yu, Anthony C., State and Religion in China: Historical and Textual Perspectives (Chicago, 2005).

Zhao, Dingxin, The Confucian-legalist state: A New Theory of Chinese History (New York Press, 2015).

Zhou, Bokan, 周伯戡, Huiyuan shamen bu jing wangzhe lun de lilun jichu 慧遠沙門不敬王者 論的理論基礎, Taida lishi xue bao 臺大歷史學報 9 (1982) 67-92.

Zürcher, Erik, The Buddhist Conquest of China: The Spread and Adaptation of Buddhism in Early Medieval China (3rd edition) (Leiden, 2007). 